\title{
Phytochemical Constituents from Aloe Vera Leaves and Garden Grass Seeds and Their Utilization as Anticancer Activity
}

\author{
Safaa F. Faid \\ Department of Home Economics, \\ Faculty of Specific Education, Ain Shams University, Cairo, Egypt \\ Department of Food Science and Nutrition, College of Science, Taif University
}

\begin{abstract}
This study was achieved to estimate the chemical composition, antioxidant activity, phenolic acids, and flavonoids compounds and also there fractionated using HPLC to Aloe Vera leaves and garden cress seeds. Moreover, the determined effect of Aloe Vera and garden cress on cultured tumor breast cancer (MFC-7) in methanol extract and there compared with Vinblastine Salfate as control and of 5-Flurourasil as references against on breast cancer cell line.
\end{abstract}

The results illustrated that the Aloe Vera was the highest in ash content, crude fiber and total carbohydrate in addition garden cress had the highest in protein content and total lipid. Minerals content observed that the iron, magnesium, manganese, and zinc were the major component in Aloe Vera whereas, calcium, potassium, and sodium were the major components in garden cress. Antioxidant activity was found high in Aloe Vera leaves and garden cress seeds. Furthermore, the Aloe Vera leaves and garden cress seeds had contained from eight compounds from the phenolic acids (ferulic, $P$-coumaric, caffic, vanillic, cinamic, chlorogenic and ellagic acids) and flavonoid compounds as quercetin, merictin, rutin, narengin, rhamentin, apiginin, kampferol, and quercitrin.

Inhibitory activity of Garden cress against breast carcinoma cells was detected using MTT assay, Vinblastine Sulfate as control and 5-Flurourasil as references under these experimental conditions with $\mathrm{IC}_{50}$ were $36.4 \pm 2.9,5.9 \pm 0.8 \mathrm{and} 28 \pm 2.7 \mu \mathrm{g} / \mathrm{ml}$ (after 48 hours incubation) and also in Aloe Vera with $\mathrm{IC}_{50}$ were $28.2 \pm 0.9,4.39 \pm 0.25$ and $28 \pm 2.7 \mu \mathrm{g} / \mathrm{ml}$ (after $48 \mathrm{hours}$ incubation).

From the above results, it could be recommended that the Aloe Vera leaves and garden cress seeds had contained rich amount from bioactive compounds as natural antioxidants which may be a delay of carcinoma diseases and elevated life expectancy. Key words: Aloe Vera, Garden cress, Breast Cancer, Antitumor

\section{INTRODUCTION}

Cancer performs with transformations in DNA, which could lead the cells on how to grow and divide. Normal cells have the power to reform generality of the transformations in their DNA, but the mutation which is not repaired which may be causing the cells to grow to begin to be cancerous cells (1).

Medicinal plants have played a role in taking action to reduce human health issues and supportive of the human body in the Stone Age. The World Health Organization (WHO) observed that $80 \%$ of the peoples in Asian and African countries rely on traditional medicines. (2).

Plants, since ancient times, health are received an advantage by all cultures and also can be obtained from medicines. It has been evaluated that about $80-85 \%$ of the world people had depended on conventional medicines for their primary health care necessarily and it is supposed to be the case that a great part of conventional treatment includes the utilization of plant extracts or their active components $(3,4)$. In spite of the fact that a lot of recent are studies and may be achieved for promoting the therapy and control of cancer advancement. The major effects of synthetic drugs are connected with side influences. Therefore natural medication, like utilize of the plants or their extractions is could be useful to prevent cancer (5).

Cancer is basically a disease of uncontrolled cell division. Cells had contained more variation techniques to limit cell division, repair DNA damage, and prohibit the advancement of cancer. May be due to this, it's could be that cancer improves in a multi-step, in which various techniques usually fail before a critical mass has arrived and cells begin to be cancerous. These variations, cancer cells had contained the power to migrate to any sides of the body, this process is called metastasis, and to elevate the increasing of new blood vessels, which award tumor cells supply of oxygen and nutrients. Cancer cells may fail to subject programmed cell death may be caused by DNA damage (6).

Aloe Vera (Aloe barbadensis Miller), s have been very promising treatment for the therapy of confirmed types of cancer. It had contained a compound is called 1.8 dihydroxy-3 (hydroxymethyl) - anthraquinone which had due to cancer cells death (7). Aloe Vera has could be effects on as anti-neoplastic and anti-proliferative on various cancer kinds and cell lines. Also, it has a high amount of possibility to avail as an adjunct to traditional chemotherapeutic, as these findings explained the possibility for synergy with choosing chemotherapeutic agents, acceptable for a lowering in drug dose (8).

Garden cress (Lepidium sativum L.,) belongs to the Brassicaceae or Cruciferae family of the plant kingdom that includes cruciferous vegetables. Garden cress is an annual polymorphous species with edible seeds, leaves, and stems (9). It is widely used in the Middle East in folk medicine and the seeds are said to have the rmogenic, depurative, rubefacient, tonic, abortive, ophthalmic, diuretic, contraceptive, and anti-cancer activities (10, 11). They are also used for bone healing (12), reducing inflammation, cough (bronchial asthma) (13) and anemia (11). 
Garden cress seed has been used in curing many health-related complications by our ancients. It has been used in the treatment of many health problems such as hypertension, kidney diseases, prevention of cancer and mild glycemia. Garden cress seed is widely used to heal fractures and to increase milk secretion during lactation. Garden cress seed also possesses a wide range of antioxidants. Fatty acids of Garden cress seed oil helps in preventing coronary heart diseases (14).

The aim of this investigation was carried out to identification of phytochemical constituents from Aloe Vera and Garden Grass and their utilization as antioxidant activity and their utilization as anticancer activity.

Materials

\section{MATERIALS AND METHODS}

The plant Aloe Vera was bought at the flower market. The leaves were washed with distilled water and peel was separated from the gel. Extracts was isolated by using methanol $70 \%$ as a solvent.

Garden cress (Lepidium sativum L.) seeds were purchased from the local market. The seeds were ground in a grinder and the seed powder was packed in an airtight plastic container.

Mammalian cell lines, MCF-7 cells (human breast cancer cell line) were obtained from the American Type Culture Collection (ATCC, Rockville, MD).

Dimethyl sulfoxide (DMSO), MTT and trypan blue dye was purchased from Sigma (St. Louis, Mo., USA). Fetal Bovine serum, DMEM, Vinblastine Sulfate and 5-Flurourasil were purchased from Lonza (Belgium)

\section{Methods}

\section{Determination of the chemical continuance and minerals content of Aloe Vera and garden cress}

Proximate analysis including crude protein, crude lipids, ash, crude fibers and total carbohydrates were determined in the raw materials (Aloe Vera and garden cress) according to the methods of AOAC (15).

Minerals content were determined in the diluted solution of ash raw materials (Aloe Vera and garden cress) using the atomic absorption spectrophotometer (3300 Perkin-Elme) as described in by AOAC (15).

\section{Determination of total phenolic and flavonoid contents}

The phenolic content of the extract was measured according to the method of Debnath et al. (16) and Im et al. (17). The result was expressed as percentage of gallic acid equivalents (GAEs) mg per $100 \mathrm{~g}$ dry weight. Furthermore, the total flavonoid compounds were measured by the reported colorimetric assay and the result was expressed as percentage of Quercetin equivalents (QEEs) mg per $100 \mathrm{~g}$ dry weight according to Debnath et al. (16) and Lee et al. (18).

\section{1,1-diphenyl-2-picrylhydrazyl radical-scavenging activity (DPPH)}

The ability of the extract components to donate hydrogen atom or electron and scavenge 1,1-diphenyl-2-picrylhydrazyl (DPPH) radical was determined by the method of Samad $\boldsymbol{e t}$ al. (19). The radical-scavenging activity of the tested samples, expressed as percentage inhibition of DPPH, was calculated according to the formula $(\%) \mathrm{AA}=[(\mathrm{A} 0-\mathrm{At}) / \mathrm{A} 0] \times 100$

Where: At is the absorbance value of the tested sample and A0 is the absorbance value of DPPH, in particular time. Percent inhibition after 30 min was plotted against concentration, and the equation for the line was used to obtain the IC50 value. A lower IC50 value indicates greater antioxidant activity.

\section{2,2-Azino-bis(3-ethylbenzthiazoline-6-sulphonic acid) radical-scavenging activity (ABTS)}

The ABTS method is based on the reduction of the green ABTS radical cation $(7.00 \mathrm{mmol} / \mathrm{L})$ that was obtained by its oxidation with equal volume of potassium persulphate $(2.45 \mathrm{mmol} / \mathrm{L})$, (20) for $12-16 \mathrm{~h}$ at $4^{\circ} \mathrm{C}$ in the dark. The radicalscavenging activity of the tested samples, expressed as percentage inhibition of ABTS $\bullet$, were calculated according to the formula

(\%) $\mathrm{AA}=[(\mathrm{A} 0-\mathrm{At}) / \mathrm{A} 0] \times 100$

Where: A0 and at are the absorbance values of the ABTS and the test sample, at particular times, respectively. Percent inhibition after $10 \mathrm{~min}$ was plotted against concentration, and the equation for the line was used to obtain the IC50 value. A lower IC50 value indicates greater antioxidant activity.

\section{Fractionation and identification of phenolic acid and flavonoids compounds}

The phenolic and flavonoid compounds of Aloe Vera and garden cress extract were determined using HPLC according to Goupy et al. (21). An HP1100 HPLC system equipped with an alpha bond C 18 125A column (4.6.250 mm, particle size 5 $\mu \mathrm{m})$ and coupled with agilent 1100 series Chem. Station software was used for quantifying the individual phenolic acids. The mobile phases consisted of $2.0 \%$ acetic acid in distilled water (A) and acetonitrile (B). The column was eluted at $1 \mathrm{ml} / \mathrm{min}$ under a linear gradient from $5 \%$ mobile phase B to $75 \%$ over $20 \mathrm{~min}$, to $100 \%$ over $5 \mathrm{~min}$. Sample injection volumes were $20 \mu \mathrm{l}$. Compounds were detected at $280 \mathrm{~nm}$ and $330 \mathrm{~nm}$ for phenolic and flavonoid compounds with an HP1100 series ultraviolet (UV) diode array detector. Standards obtained from Sigma Co. were dissolved in a mobile phase and injected into HPLC. Retention time and peak area were used to calculation of phenolic and flavonoid compounds concentration by the data analysis of HEWLLET packared software. 


\section{Biological Tests}

\section{In vitro cell culture activities}

MCF-7 cells (human breast cancer cell line), was has grown on RPMI-1640 medium supplemented with 10\% inactivated fetal bovine serum (FCS) and $1 \%$ penicillin/streptomycin $(10.000 \mathrm{units} / \mathrm{ml} / 10 \mathrm{mg} / \mathrm{ml})$ The cells were maintained at $37^{\circ} \mathrm{C}$ in a humidified atmosphere with 5\% $\mathrm{CO} 2$ and were subculture two to three times a week.

\section{Effect of Aloe Vera and garden cress on cultured tumor breast cancer (MFC-7)}

For antitumor assays, the tumor cell lines (MFC-7) were suspended in medium at concentration $5 \times 10^{4}$ cell/well in Corning ${ }^{\circledR}$ 96-well tissue culture plate, and incubated for $24 \mathrm{hr}$. The tested compounds were then added into 96-well plates (three replicates) to achieve ten concentrations for each compound. Vinblastine Sulfate control with media or Dimethyl sulfoxide (DMSO) $0.5 \%$ were run for each 96 well plate as a control. After incubating for $48 \mathrm{~h}$, the numbers of viable cells were determined by the MTT test. Briefly, the media was removed from the 96 well plates and replaced with $100 \mu \mathrm{l}$ of fresh culture RPMI 1640 medium without phenol red then $10 \mu \mathrm{l}$ of the $12 \mathrm{mM}$ MTT stock solution (5 mg of MTT in $1 \mathrm{~mL}$ of PBS) to each well including the untreated controls. The 96 well plates were then incubated at $37^{\circ} \mathrm{C}$ and $5 \% \mathrm{CO}_{2}$ for 4 hours. An $85 \mu \mathrm{l}$ aliquot of the media was removed from the wells, and $50 \mu 1$ of DMSO was added to each well and mixed thoroughly with the pipette and incubated at $37^{\circ} \mathrm{C}$ for $10 \mathrm{~min}$. Then, the optical density was measured at $590 \mathrm{~nm}$ with the micro plate reader (Sun Rise, TECAN, Inc, USA) to determine the number of viable cells and the percentage of viability was calculated as $[(\mathrm{ODt} / \mathrm{ODc})] \times 100 \%$ where ODt is the mean optical density of wells treated with the tested sample and ODc is the mean optical density of untreated cells. The relation between surviving cells and drug concentration is plotted to get the survival curve of each tumor cell line after treatment with the specified compound. The 50\% inhibitory concentration $\left(\mathrm{IC}_{50}\right)$, the concentration required to cause toxic effects in 50\% of intact cells, was estimated from graphic plots of the dose response curve for each conc. using Graphpad Prism software (San Diego, CA. USA) (22).

\section{Statistical analysis:}

The statistical analysis was performed by one-way analysis of variance (ANOVA) followed by Dunnet's test for the estimation of total variation in a set of data. Results were communicated in terms of mean values with $( \pm \mathrm{SD})$ where the probability $(\mathrm{p}<0.01)$ of getting the result was considered as significant.

\section{RESULTS AND DISCUSSION}

\section{Chemical continuance and minerals content of Aloe Vera and garden cress}

The results from the chemical composition of Aloe Vera leaves and garden cress seeds are shown in Table (1). From the results it could be noticed that the Aloe Vera was the highest in ash content, crude fiber and total carbohydrate were 14.21, 12.35 and $54.70 \%$ than garden cress was 5.55, 6.11 and 33.99\%, respectively. Ash content is the first step to make ready a biological sample for particularly elemental analysis. For the reason that specific samples are elevated in certain minerals, therefore, ash content begins to be of great significance (23). Carbohydrates are a major source of energy and non-digestible polysaccharides is made up of the major portion of dietary fiber. Carbohydrates also provide as viscosity, stability to emulsions, water-holding capacity, desirable textures and also supply the feeling full in the stomach (23).

Moreover, the results observed that the garden cress had the highest in protein content and total lipid were 24.37 and 26.98 than Aloe Vera was 14.21 and 2.93\%, respectively. Present results are in agreement with Al-Jasass and Al-Jasser (24) who reported that crude fat content, ash content, crude protein content and crude fiber content in L. sativum seeds was $23.19 \%$, 7.1\%, 24.19\% and $11.9 \%$, respectively. Zia-Ul-Haq et al. (25) reported that proximate analysis of L. sativum seeds indicated the presence of high amounts of protein (24.18\%), fiber (6.75\%), lipids (28.03\%), ash (3.92\%), moisture (3.92\%) and carbohydrates $(32.87 \%)$.

Meanwhile, research on Aloe Vera tissues found 7.56-15.4\% crude proteins (26). The major structural components of foods are lipids, proteins, and carbohydrates were analyzed of great significance for careful nutritional information (23).

Table (1): chemical continuance $(\mathrm{g} / 100 \mathrm{~g})$ and minerals content $(\mathrm{mg} / 100 \mathrm{~g})$ of Aloe Vera and garden cress on dry weight bases

\begin{tabular}{|c|c|c|}
\hline Chemical analysis & Aloe Vera & Garden Cress \\
\hline Protein & $14.21 \pm 1.38$ & $24.37 \pm 1.78$ \\
\hline Crude lipids & $2.93 \pm 0.06$ & $26.98 \pm 1.14$ \\
\hline Crude fiber & $12.35 \pm 0.97$ & $6.11 \pm 0.08$ \\
\hline Ash content & $15.81 \pm 1.02$ & $8.55 \pm 0.09$ \\
\hline Total carbohydrates & $54.70 \pm 3.27$ & $33.99 \pm 2.92$ \\
\hline Minerals content mg/100g & $246.27 \pm 10.35$ & $255.8 \pm 10.28$ \\
\hline Calcium & $5.07 \pm 0.21$ & $4.12 \pm 0.14$ \\
\hline Iron & $487.38 \pm 7.36$ & $643.0 \pm 9.58$ \\
\hline Potassium & $750.69 \pm 6.28$ & $195.25 \pm 3.46$ \\
\hline Magnesium & $4.33 \pm 0.15$ & $0.41 \pm 0.05$ \\
\hline Manganese & $4.19 \pm 0.17$ & $2.10 \pm 0.17$ \\
\hline Zinc & $22.70 \pm 0.98$ & $42.55 \pm 3.49$ \\
\hline Sodium & $3)$. & \\
\hline
\end{tabular}

Each value is expressed as mean \pm standard deviation $(n=3)$. 
The results from the minerals content in the same Table showed that the iron, magnesium, manganese and zinc were the major component in Aloe Vera $(5.07,750.69,4.33$ and $4.19 \mathrm{mg} / 100 \mathrm{~g}$ ) and the minor component of garden cress was 4.12, $195.25,0.41$ and $2.10 \mathrm{mg} / 100$, respectively. Moreover, the major component in garden cress were calcium, potassium and sodium $(255.8,643.0$ and $42.00 \mathrm{mg} / 100 \mathrm{~g}$, respectively) and the minor component of Aloe Vera was 246.27, 487.38 and 22.7 $\mathrm{mg} / 100 \mathrm{~g}$, respectively.

Magnesium plays an important function in lipid membrane stabilization, the action of copying and metabolic processes $(27,28)$. Manganese is essential for metabolism, reproduction, immunological system and growth of connective tissues in animal. But high level of $\mathrm{Mn}$ is toxic to the body, which causes neurodegenerative disorders (29). Potassium and Sodium both are essential and they play an important function in the cellular homeostasis (30). Calcium is the major metal in bone and ready to give help for adjusting skeletal and cardiac muscle contractions (31). Zinc is great significance and plays a function in the structure of proteins in addition in the enzymatic catalysis (32). Zinc and Potassium are effective to enhance the concentration of insulin and prevent diabetes Underwood (33).

\section{Phytochemical content and activity of Aloe Vera and garden cress}

Total phenolics and total flavonoids compounds were determined in methanol extract for Aloe Vera and garden cress and the results are tabulated in Table (2). The results observed that the significant increased in the total phenolic and flavonoid contents from garden cress (57.12 GAE/100g and $43.38 \mathrm{QE} / 100 \mathrm{~g})$ than Aloe Vera was significantly lower (20.28 GAE/100g and 15.49 QE/100g, respectively). These results are in confirmed with Vidic et al. (34) observed that the A. Vera had a significantly lower concentration of total phenolic and total flavonoid in $\mathrm{m}$ ethanolic extracts were $0.11 \pm 0.01 \mathrm{GAE} / \mathrm{g}$ and $0.5 \pm$ $0.003 \mathrm{QE} / \mathrm{g}$, respectively. Indumathy and Aruna (35) estimated the free radical scavenging activity of total phenolic and flavonoid compounds extracted from garden cress seeds was the total phenols $(8.651 \mathrm{mgGAE} / \mathrm{gm})$ and flavonoids (4.023 mg $\mathrm{CAE} / \mathrm{gm})$. Methanolic extract of garden cress seeds observed maximum antioxidant activity by inhibiting DPPH and hydroxyl radical.

From the same Table it could be showed that the results for the IC50 values using DPPH and ABTS were significantly decreased from garden cress (1.557 and $0.126 \mathrm{mg} \mathrm{GAE} / \mathrm{ml}$,) than Aloe Vera was 1.837 and $0.132 \mathrm{mg}$ GAE/ml, respectively. These results confirmed that when the total phenolic and flavonoid content were increased the IC50 values of DPPH and ABTS were significantly decreased and its free radical scavenging activities were strong. Hęs $\boldsymbol{e t ~ a l . ~ ( 3 6 ) ~ f o u n d ~ t h a t ~ t h e ~ w a t e r ~ e x t r a c t s ~}$ total phenolic acids of Aloe Vera were $17.85 \mathrm{mg} / \mathrm{g}$ dry weight and the DPPH and ABTS radical scavenging activity ability from 4.32 to 8.87 and 0.58 to $0.87 \mathrm{mg}$ of Trolox per $1 \mathrm{~g}$ dry weight respectively.

Table (2): Phytochemical content and activity of Aloe Vera and garden cress

\begin{tabular}{|c|c|c|}
\hline Phytochemical content & Aloe Vera & Garden Cress \\
\hline Total phenolic & $20.28 \pm 1.23$ & $57.12 \pm 2.26$ \\
\hline Total flavonoids & $15.49 \pm 1.35$ & $43.38 \pm 2.17$ \\
\hline $\mathrm{DPPH} \mathrm{IC}_{50}(\mathrm{mg} / \mathrm{ml})$ & $1.837 \pm 0.01$ & $1.56 \pm 0.04$ \\
\hline $\operatorname{ABTS~IC}_{50}(\mathrm{mg} / \mathrm{ml})$ & $0.132 \pm 0.001$ & $0.126 \pm 0.001$ \\
\hline
\end{tabular}

Each value is expressed as mean \pm standard deviation $(n=3)$.

$\mathrm{mg} / 100 \mathrm{~g}$ gallic acid equivalent $\mathrm{mg} / 100 \mathrm{~g}$ Quercetin equivalent

IC50 (mg GAE /mL): The concentration at which 50\% is inhibited

\section{Fractionation and identification of phenolic acid and flavonoids compounds}

For over four million years, flavonoids and other phenolic substances from medicinal herbs have been used or consumed by humans so as to live healthily and fight against undesirable diseases (37). As a plant secondary metabolites, flavonoids and other phenolics are found in several plant species, type and amount of the chemical components are vary depending on species and affecting by environmental factors i.e., mineral at the growth locality and geographic origin (38).

Fractionation and identification of phenolic acid and flavonoids compounds by HPLC results are reported in Table (3). The results indicate that eight phenolic compounds have been quantified in garden cress seed and Aloe Vera leave extract. $P$ Coumaric, gallic, vanilic and chlorogenic acids acid are the major compounds in Aloe Vera extract. Whilst, ferulic, caffic, cinamic and ellagic acids are the major compounds in garden cress extract. These phytochemicals are considered a potential source of functional food ingredients for their high antioxidant capacity (39).

Table (3): Fractionation and identification of phenolic acids $\mathrm{mg} / 100 \mathrm{~g}$

\begin{tabular}{|c|c|c|c|c|}
\hline \multirow[t]{2}{*}{ Phenolic acids } & \multicolumn{2}{|c|}{ Aloe Vera } & \multicolumn{2}{|c|}{ Garden Cress } \\
\hline & $\mathrm{mg} / 100 \mathrm{~g}$ & $\%$ & $\mathrm{mg} / 100 \mathrm{~g}$ & $\%$ \\
\hline Ferulic & 0.23 & 4.16 & 0.78 & 7.97 \\
\hline$P$-Coumaric & 0.94 & 17.0 & 1.13 & 11.54 \\
\hline Gallic & 0.92 & 16.64 & 1.00 & 10.21 \\
\hline Caffeic & 0.36 & 6.51 & 1.42 & 14.50 \\
\hline Vanillic & 1.58 & 28.57 & 2.33 & 23.80 \\
\hline Cinnamic & 0.27 & 4.88 & 0.68 & 6.95 \\
\hline Chlorogenic & 0.78 & 14.10 & 1.37 & 13.99 \\
\hline Ellagic & 0.45 & 8.14 & 1.08 & 11.03 \\
\hline
\end{tabular}


The present research has found that eight flavonoid compounds were quantitatively identified in garden cress seeds and Aloe Vera extracts and the results are shown in Table (4). The quercetin, nargenin, and kampherol were the major components in Aloe Vera seeds extract and it showed 19.44, 13.72 and 23.44\%, respectively. Meanwhile, garden cress extract illustrated that the rutin and qurcitrin were the major compounds (27.92 and22.20\%, respectively) and also merictin, rhametin and apiginin compounds were nearly equal in Aloe Vera and garden cress extracts. Phytochemicals is a flavonoid that has been caused to come to a place of major benefit for the reason that it is a strong antioxidant with certain anti-cancer influences. Its structure has contained a double bond in the $\mathrm{C}$ ring and a 4-oxo group, which increases its antioxidant activity (40).

Table (4): Fractionation and identification of flavonoids compounds $\mathrm{mg} / 100 \mathrm{~g}$

\begin{tabular}{|c|c|c|c|c|}
\hline \multirow[t]{2}{*}{ Flavonoids compounds } & \multicolumn{2}{|c|}{ Aloe Vera } & \multicolumn{2}{|c|}{ Garden Cress } \\
\hline & $\mathrm{mg} / 100 \mathrm{~g}$ & $\%$ & $\mathrm{mg} / 100 \mathrm{~g}$ & $\%$ \\
\hline Quercetin & 0.34 & 19.44 & 0.52 & 11.90 \\
\hline Merictin & 0.16 & 9.15 & 0.42 & 9.61 \\
\hline Rutin & 0.23 & 13.15 & 1.22 & 27.92 \\
\hline Narengin & 0.24 & 13.72 & 0.35 & 8.01 \\
\hline Rhamentin & 0.057 & 3.26 & 0.13 & 2.97 \\
\hline Apiginin & 0.082 & 4.69 & 0.18 & 4.12 \\
\hline Kampferol & 0.41 & 23.44 & 0.58 & 13.27 \\
\hline Quercitrin & 0.23 & 13.14 & 0.97 & 22.20 \\
\hline
\end{tabular}

\section{Inhibitory of the activity human breast cancer cell line (MCF-7) using garden cress extracts}

The effect of garden cress extract against human breast cancer was estimated by the MTT assay. Garden cress extract was great activity against MCF-7 cell line and the results are summarized in Table (5, 6 and 7) and Figures (1, 2 and 3). From the resultant, the highest percentage inhibition value was $95.11 \%$ from garden cress extract at concentration $500 \mu \mathrm{g} / \mathrm{ml}$. Moreover, the finding showed that when the highest dose from garden cress extract to give the greatest response may be caused the garden cress extract has contained compounds against cancer. Minimum inhibition was observed at extract concentration of 2.0, 3.9, 7.8 and $15.6 \mu \mathrm{g} / \mathrm{ml}$ were lower inhibition cell lines than Vinblastine Sulfate as control and 5-Flurourasil as a references, these means that the highest concentration of garden cress increased in inhibition the growth of MCF-7 cell line whereas, the lower concentration from Vinblastine Sulfate and 5-Flurourasil increased in inhibition the growth of MCF-7 cell line. Moreover, inhibitory activity of garden cress extract, Vinblastine Sulfate as control and 5-Flurourasil as a references against breast carcinoma cells (MFC-7) were detected using MTT assay under these experimental conditions with $\mathrm{IC}_{50}=36.4 \pm 2.9,5.9 \pm 0.8$ and $28 \pm 2.7 \mu \mathrm{g} / \mathrm{ml}$, respectively (after 48 hours incubation). These results confirmed by Swanson et al. (41) studied the aqueous extract of garden cress extract seeds for their cytotoxic and apoptotic effects on MCF-7 cancer cells and normal HFS cells the cytotoxic effect of MCF-7 cells was higher than normal cells with an application of 50\% extract concentration, and this cytotoxic effect was observed to be caused by apoptotic effect. At $75 \%$ concentration, the cytotoxic effect was detected with necrosis. Moreover, overabundant production of free radical will be exacerbate oxidative harmful to proteins, lipids and DNA and even lead to cell death (42).

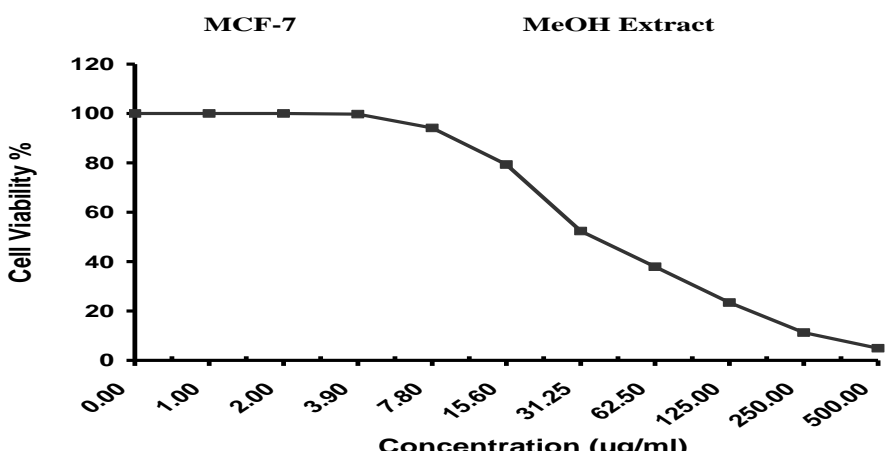

Table (5) and Figure (1): Inhibitory activity of garden cress extract against on human breast cancer cell line

\begin{tabular}{|c|c|c|c|}
\hline Sample conc. $(\mu \mathrm{g} / \mathrm{ml})$ & Viability $\%$ & Inhibitory $\%$ & S.D. $( \pm)$ \\
\hline 500 & 4.89 & 95.11 & 0.72 \\
\hline 250 & 11.25 & 88.75 & 0.91 \\
\hline 125 & 23.40 & 76.6 & 0.63 \\
\hline 62.5 & 37.94 & 62.06 & 1.68 \\
\hline 31.25 & 52.37 & 47.63 & 2.15 \\
\hline 15.6 & 79.29 & 20.71 & 0.83 \\
\hline 7.8 & 94.15 & 5.85 & 0.79 \\
\hline 3.9 & 99.76 & 0.24 & 0.12 \\
\hline 2 & 100 & 0 & \\
\hline 1 & 100 & 0 & \\
\hline 0 & 100 & 0 & \\
\hline
\end{tabular}


Inhibitory activity against Breast carcinoma cells was detected using MTT assay under these experimental conditions with IC $C_{50}$ $=36.4 \pm 2.9 \mu \mathrm{g} / \mathrm{ml}$ (after 48 hours incubation).

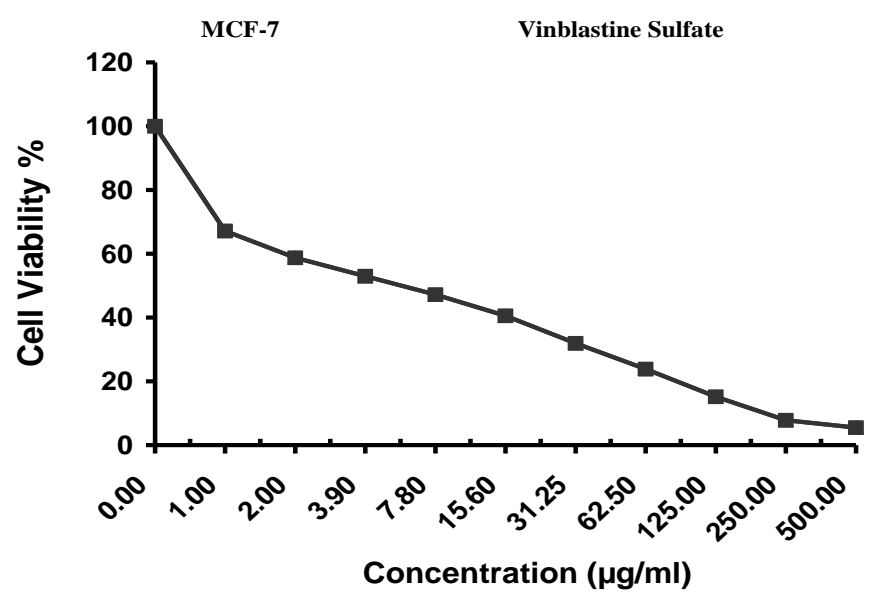

Table (6) and Figure (2): Inhibitory activity of Vinblastine Sulfate as control against on human breast cancer cell line

\begin{tabular}{|c|c|c|c|}
\hline Sample conc. $(\mu \mathrm{g} / \mathrm{ml})$ & Viability $\%$ & Inhibitory $\%$ & S.D. $( \pm)$ \\
\hline 500 & 5.49 & $94.51 \pm 0.23$ & 0.23 \\
\hline 250 & 7.82 & $92.18 \pm 0.16$ & 0.16 \\
\hline 125 & 15.18 & $84.82 \pm 0.49$ & 0.49 \\
\hline 62.5 & 23.87 & $76.13 \pm 1.59$ & 1.59 \\
\hline 31.25 & 31.95 & $68.05 \pm 0.72$ & 0.72 \\
\hline 15.6 & 40.56 & $59.44 \pm 1.18$ & 1.18 \\
\hline 7.8 & 47.21 & $52.79 \pm 2.35$ & 2.35 \\
\hline 3.9 & 52.94 & $47.06 \pm 1.78$ & 1.78 \\
\hline 2 & 58.76 & $41.24 \pm 0.24$ & 0.24 \\
\hline 1 & 67.16 & $32.84 \pm 0.32$ & 0.32 \\
\hline 0 & 100 & & \\
\hline
\end{tabular}

Inhibitory activity against Breast carcinoma cells was detected under these experimental conditions with $I C_{50}=5.9 \pm 0.8 \mu \mathrm{g} / \mathrm{ml}$ (after 48 hours incubation).

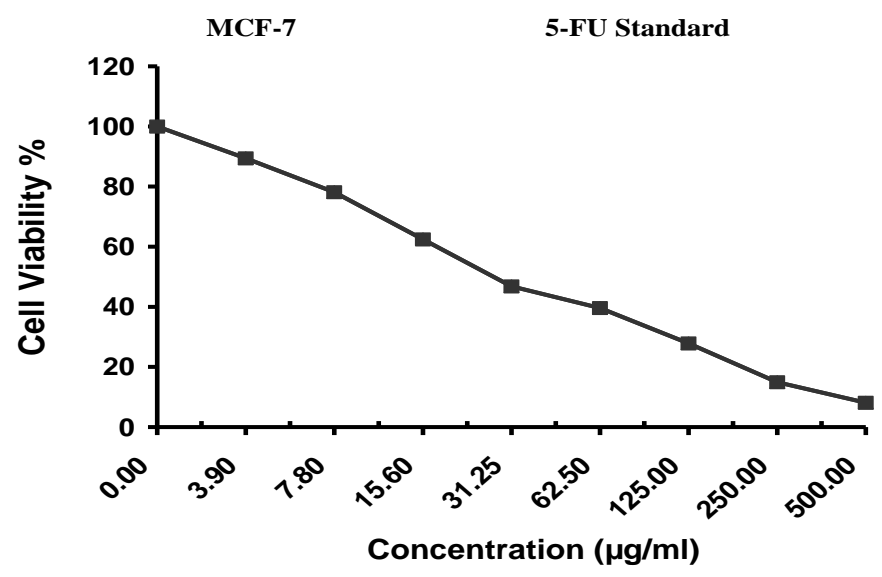

Table (7) and Figure (3): Inhibitory activity of 5-Flurourasil as references against on human breast cancer cell line

\begin{tabular}{|c|c|c|c|}
\hline Sample conc. $(\mu \mathrm{g} / \mathrm{ml})$ & Viability \% & Inhibitory \% & S.D. $( \pm)$ \\
\hline 500 & 8.12 & $91.88 \pm 0.24$ & 0.24 \\
\hline 250 & 14.91 & $85.09 \pm 0.33$ & 0.33 \\
\hline 125 & 27.84 & $72.16 \pm 0.18$ & 0.18 \\
\hline 62.5 & 39.58 & $60.42 \pm 0.62$ & 0.62 \\
\hline 31.25 & 46.79 & $53.21 \pm 2.31$ & 2.31 \\
\hline 15.6 & 62.43 & $37.57 \pm 1.69$ & 1.69 \\
\hline 7.8 & 78.15 & $21.85 \pm 0.41$ & 0.41 \\
\hline 3.9 & 89.41 & $10.59 \pm 0.73$ & 0.73 \\
\hline 0 & 100 & & \\
\hline
\end{tabular}


Inhibitory activity against Breast carcinoma cells was detected under these experimental conditions with $I_{50}=28 \pm 2.7 \mu \mathrm{g} / \mathrm{ml}$ (after 48 hours incubation).

\section{Inhibitory of the activity human breast cancer cell line (MCF-7) using Aloe Vera extract.}

The effect of Aloe Vera extract assayed for their in vitro anticancer activity against MCF-7 cancer cells and were found to exhibit marked toxicity are in Table $(8,9$ and 10) and Figures $(4,5$ and 6$)$. The results showed that the cytotoxic influence of the Aloe Vera extract found in this study was caused significantly increased cell cytotoxicity, from the minimize to maximum concentrations ranging from 1.0 to $500 \mu \mathrm{l} / \mathrm{ml}$ due to constituents of Aloe Vera extract which it can exhibit cytotoxic activity against breast carcinoma cells (MCF-7). Moreover the vinblastine sulfate increased in inhibition the growth of MCF-7 cell line in the lower concentration at level 3.9, 7.8, 15.6 and $31.25 \mu \mathrm{g} / \mathrm{ml}$ was give inhibition 4.83, 13.76, 29.17 and $54.98 \%$, respectively.. Moreover, inhibitory activity of Aloe Vera extract, Vinblastine Sulfate as control and 5-Flurourasil as a references against breast carcinoma cells (MFC-7) were detected using MTT assay under these experimental conditions with $\mathrm{IC}_{50}=28.2 \pm$ $0.9,4.26 \pm 0.2$ and $4.39 \pm 2.5 \mu \mathrm{g} / \mathrm{ml}$, respectively (after 48 hours incubation). These outcomes are in conformity with before research which observed that the Aloe Vera extract or its components considerably decreased the reproduction of cancer cells in vitro and in vivo whilst being lower toxic in the direction of the normal cells (43). Moreover the results confirmed by Sundarraj et al. (44) who found that the vital bioactive components showed anticancer possibility by various mechanisms involved suppression of signaling pathways, death induction and cell-cycle stopping. Jurasz et al. (45) found that tumor cellinduced aggregation of platelets is essential for the survival of tumor cells and its effective metastasis. a-Bulnesene current in hexane extract prevents platelet aggregation (46). This confirms that Aloe Vera extract induces cell death via apoptosis. Difference other research has also assured that the various constituents of Aloe Vera encourage cell cycle stopping and death in cancer cells $(\mathbf{4 7}, \mathbf{4 8})$.

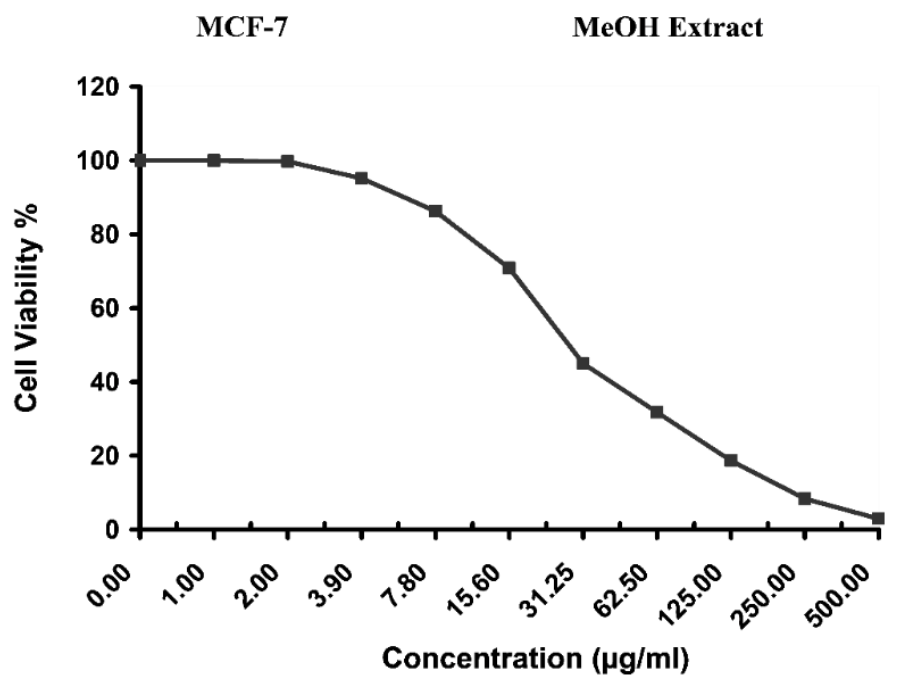

Table (8) and Figure (4): Inhibitory activity of Aloe Vera extract against on human breast cancer cell line

\begin{tabular}{|c|c|c|c|}
\hline Sample conc. $(\mu \mathrm{g} / \mathrm{ml})$ & Viability $\%$ & Inhibitory $\%$ & S.D. $( \pm)$ \\
\hline 500 & 2.91 & 97.09 & 0.37 \\
\hline 250 & 8.40 & 91.6 & 0.26 \\
\hline 125 & 18.65 & 81.35 & 0.93 \\
\hline 62.5 & 31.78 & 68.22 & 1.46 \\
\hline 31.25 & 45.02 & 54.98 & 2.37 \\
\hline 15.6 & 70.83 & 29.17 & 2.18 \\
\hline 7.8 & 86.24 & 13.76 & 1.53 \\
\hline 3.9 & 95.17 & 4.83 & 0.61 \\
\hline 2 & 99.76 & 0.24 & 0.08 \\
\hline 1 & 100 & 0 & \\
\hline 0 & 100 & 0 & \\
\hline
\end{tabular}

Inhibitory activity against breast carcinoma cells was detected using MTT assay under these experimental conditions with IC $_{50}=$ $28.2 \pm 0.9 \mu \mathrm{g} / \mathrm{ml}$ (after 48 hours incubation). 


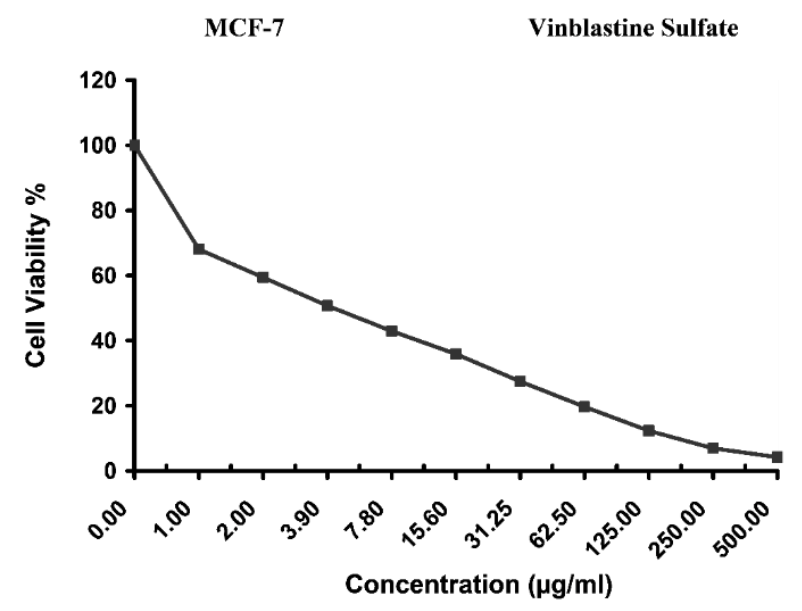

Table (9) and Figure (5): Inhibitory activity of Vinblastine Salfate as control against on human breast cancer cell line

\begin{tabular}{|c|c|c|c|}
\hline Sample conc. $(\mu \mathrm{g} / \mathrm{ml})$ & Viability $\%$ & & S.D. $( \pm)$ \\
\hline 500 & 5.32 & 94.68 & 0.13 \\
\hline 250 & 13.06 & 86.94 & 0.51 \\
\hline 125 & 20.92 & 79.08 & 0.27 \\
\hline 62.5 & 31.83 & 68.17 & 0.46 \\
\hline 31.25 & 42.97 & 57.03 & 0.72 \\
\hline 15.6 & 54.76 & 45.24 & 0.53 \\
\hline 7.8 & 68.94 & 31.06 & 1.16 \\
\hline 3.9 & 75.31 & 24.69 & 1.28 \\
\hline 0 & 100 & 0 & \\
\hline
\end{tabular}

Inhibitory activity against breast carcinoma cells was detected under these experimental conditions with $I C_{50}=4.39 \pm 0.25 \mu \mathrm{g} / \mathrm{ml}$ (after 48 hours incubation).

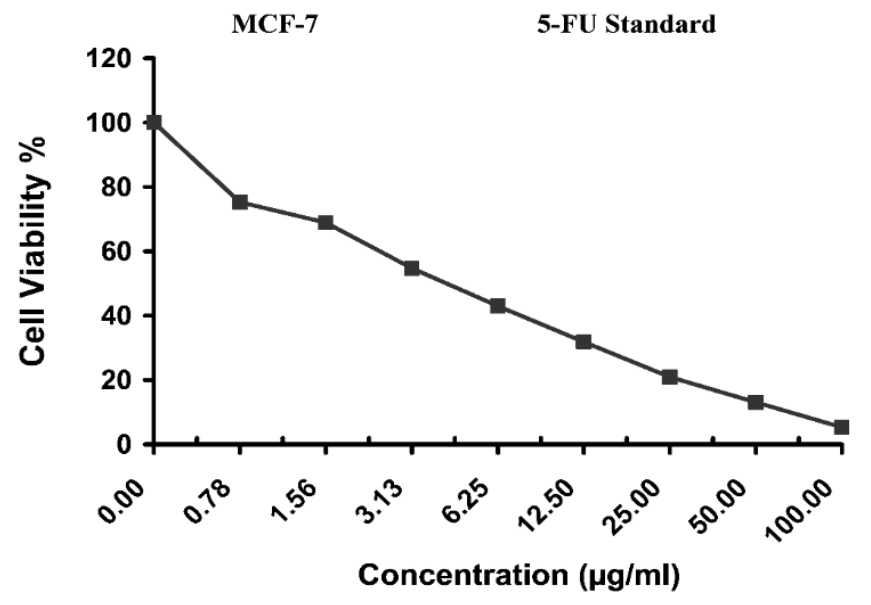

Table (10) and Figure (6): Inhibitory activity of 5-Flurourasil as references against on human breast cancer cell line

\begin{tabular}{|c|c|c|c|}
\hline Sample conc. $(\mu \mathrm{g} / \mathrm{ml})$ & Viability $\%$ & Inhibitory $\%$ & S.D. $( \pm)$ \\
\hline 500 & 8.12 & $91.88 \pm 0.24$ & 0.24 \\
\hline 250 & 14.91 & $85.09 \pm 0.33$ & 0.33 \\
\hline 125 & 27.84 & $72.16 \pm 0.18$ & 0.18 \\
\hline 62.5 & 39.58 & $60.42 \pm 0.62$ & 0.62 \\
\hline 31.25 & 46.79 & $53.21 \pm 2.31$ & 2.31 \\
\hline 15.6 & 62.43 & $37.57 \pm 1.69$ & 1.69 \\
\hline 7.8 & 78.15 & $21.85 \pm 0.41$ & 0.41 \\
\hline 3.9 & 89.41 & $10.59 \pm 0.73$ & 0.73 \\
\hline 0 & 100 & & \\
\hline
\end{tabular}

Inhibitory activity against Breast carcinoma cells was detected under these experimental conditions with $I C_{50}=28 \pm 2.7 \mu \mathrm{g} / \mathrm{ml}$ (after 48 hours incubation). 


\section{CONCLUSION}

Aloe Vera leaves and garden cress seeds are the only ones showing anticancer effects against MCF-7 cells (breast cancer cell line), Therefore, a pivotal role Aloe Vera and garden cress leaves in the health scenario is attributed to bioactive compounds as of the Polyphenols compounds as natural antioxidant, which may be a delay of carcinoma diseases and elevated life expectancy.

\section{REFERENCES}

[1] Krishnamurthi, K. (2000). Screening of natural products for anticancer and antidiabetic properties. Health Administrator. XX (1\&2): 69, (2000).

[2] Kim, JH., Gupta, SC., Park, B., Yadav, VR. and Aggarwal, BB. (2012). Turmeric (Curcuma longa) inhibits inflammatory nuclear factor (NF)-kB and NF-kB-regulated gene products and induces death receptors leading to suppressed proliferation, induced chemo sensitization, and suppressed osteoclastogenesis. Mol Nutr Food Res. 56:454-465.

[3] Elujoba, A. A., Odeleye, O. M. and Ogunyemi, C. M. (2005). Traditional medicine development for medical and dental primary health care delivery system in Africa. African Journal of Traditional, Complementary and Alternative Medicines, 2. 46. 2005.

[4] Ignacimuthu, S., Ayyanar, M. and Sivaraman, S.K. (2006). Ethnobotanical investigations among tribes in Madurai district of Tamil Nadu (India) Journal of Ethnobiology and Ethnomedicine, 2. 1. 2006.

[5] Gordon, M. C. and David, J. (2005). Plants as a source of anti-cancer agents. Journal of Ethnopharmacology, 100. 72.2005.

[6] Javed, I., Banzeer, A. and Tariq, M. (2017). Plant-derived anticancer agents: A green anticancer approach. Asian Pacific Journal of Tropical Biomedicine. 2017; 7(12):1129-1150

[7] Maram, S., Mahmoud, M. and Zakaria, A. (2015). Anticancer activity of Aloe vera and Calligonum comosumextracts separetely on hepatocellular carcinoma cells. Asian Pacific Journal of Tropical Biomedicine. May 2015; 5(5):375-381

[8] Brian, S., Anna, M. R. and Sharon, G. (2017). Anti-cancer effects of aloe-emodin: A systematic review. Journal of Clinical and Translational Research.2017; 3(4):1-14

[9] Sharma, S. and Agrawal, N. (2011). Nourishing and healing prowess of garden cress (Lepidium sativum Linn.)- A review. Indian Journal of Natural Products and Resources 2011;2(3):292-7.

[10] Mahassni, SH. and Al-Reemi, RM. (2013). Apoptosis and necrosis of human breast cancer cells by an aqueous extract of garden cress (Lepidium sativum) seeds. Saudi journal of biological sciences 2013;20 (2):131-9.

[11] Doke, S. and Guha, M. (2014). Garden cress (Lepidium sativum L.) Seed - An Important Medicinal Source: A Review. J Nat Prod Plant Resour 2014;4(1):69-80.

[12] Yadav, YC., Jain, A., Srivastava, DN. and Jain, A. (2011). Fracture healing activity of ethanolic extract of Lepidium sativum L. seeds in internally fixed rats' femoral osteotomy model. International Journal of Pharmacy and Pharmaceutical Sciences 2011;3(2):193-7.

[13] Paranjape, AN. and Mehta, AA. (2006). A Study on Clinical Efficacy of Lepidium sativum Seeds in Treatment of Bronchial Asthma. Iranian Journal of Pharmacology \& Therapeutics 2006;5(1):55-9.

[14] Prajapati, M.R. and Dave, P.H. (2018). Therapeutic and nutritional importance of garden cress seed, Journal of Pharmacognosy and Phytochemistry 2018; 7(5): 140-143

[15] AOAC (2012). Official methods of analysis, $19^{\text {th }}$ edition Association of Official Analytical Chemists. Washington DC.

[16] Debnath, T., Park, P. J., Debnath, N. C., Samad, N. B., Park, H. W. and Lim, B. O. (2011). Antioxidant activity of Gardenia jasminoides Ellis fruit extracts. Food Chemistry, 128, 697-703. doi:10.1016/j.foodchem.2011.03.090

[17] Im, K., Lee, J. Y., Byeon, H., Hwang, K. W., Kang, W., Whang, W. K. and Min, H. (2016). In vitro antioxidative and anti-inflammatory activities of the ethanol extract of eggplant (Solanum melongena) stalks in macrophage RAW 264.7 cells. Food and Agricultural Immunology, 27, $758-771$

[18] Lee, J.-H., Choi, E. J., Park, H.-S. and Kim, G. H. (2015). Evaluation of Compositae sp. plants for antioxidant activity, antiinflammatory, anticancer and antiadipogenic activity in vitro. Food and Agricultural Immunology, 25, 104-118.

[19] Samad, N. B., Debnath, T., Ye, M., Hasnat, M. A. and Lim, B. O. (2014). In vitro antioxidant and anti-inflammatory activities of Korean blueberry (Vaccinium corymbosum L.) extracts. Asian Pacific Journal of Tropical Biomedicine, 4, 807-815. doi:10.12980/APJTB.4.2014C1008

[20] Jeong, C.-H., Choi, G. N., Kim, J. H., Kwak, J. H., Heo, H. J., Shim, K.-H. and Choi, J.-H. (2009). In vitro antioxidant activities and phenolic composition of hot water extract from different parts of Cudrania tricuspidata.Journal of Food Science and Nutrition,14, 283-289.

[21] Goupy, P., M. Hugues, P. Biovin and M.J. Amiot (1999). Antioxidant composition and activity of barley (Hordeum vulgare L.) and malt extracts of isolated phenolic compounds. J. Sci. Food Agric., 79 : 1625-1634

[22] Gomha, S.M.; Riyadh, S.M.; Mahmmoud, E.A. and Elaasser, M.M. (2015): Synthesis and Anticancer Activities of Thiazoles, 1,3-Thiazines, and Thiazolidine Using Chitosan-Grafted-Poly(vinylpyridine) as Basic Catalyst. Heterocycles; 91(6):1227-1243

[23] Nielsen, S.S. (2009). Food Analysis, 4th Ed. Springer New York Dordrecht Heidelberg London. pp. 48-55.

[24] Al-Jasass, F. M. and Al-Jasser, M. S. (2012). Chemical composition and fatty acid content of some spices and herbs under Saudi Arabia conditions. The Scientific World Journal, 2012: 1-5.

[25] Zia-Ul-Haq, M., Ahmad, S., Calani, L., Mazzeo, T., Rio, D. D., Pellegrini, N. and Feo, V. D. (2012). Compositional study and antioxidant potential of Ipomoea hederacea Jacq. and Lepidium sativum L. seeds. Molecules, 17: 10306-10321.

[26] Femenia, A., Sanchez, E.S., Simal, S. and Rossello, C. (1999). Compositional features of polysaccharides from Aloe vera (Aloe barbadensis Miller) plant tissues. Carbohydrate Polymers. 39(2) 109-117.

[27] Yang, W., Lee, JY. and Nowotny, M. ( 2006) Making and breaking nucleic acids: two-Mg2+-ion catalysis and substrate specificity. Mol. Cell 22, $5-13$

[28] Payandeh J, Pfoh R. and Pai EF. (2013) The structure and regulation of magnesium selective ion channels. Biochim. Biophys. Acta 1828, 27782792

[29] Avila, DS., Puntel, RL. and Aschner, M. (2013) Manganese in health and disease. In Interrelations between essential metal ions and human diseases (eds Sigel A, Sigel H, Sigel RKO), pp.199- 227.

[30] Pohl, HR., Wheeler, JS., and Murray, HE. (2013). Sodium and potassium in health and disease. Met Ions Life Sci 2013;13:29-47.

[31] Toyoshima, C., Nakasako, M., Nomura, H. and Ogawa, H. (2000) Crystal structure of the calcium pump of sarcoplasmic reticulum at $2.6 \AA$ resolution. Nature 405, 647-655.

[32] Auld, DS. (2001). Zinc coordination sphere in biochemical zinc sites. BioMetals 14,271-313.

[33] Underwood, MK; Rosentha, MJ and Hong, S. (1986) Trace elements in human and animal nutrition, Academic, New York

[34] Vidic, D., Taric, E., Alagic, J. and Maksimovic, M. (2014). Determination of total phenolic content and antioxidant activity of ethanol extracts from Aloe spp. Bulletin of the Chemists and Technologists of Bosnia and Herzegovina 42: 5 -10.

[35] Indumathy, R and Aruna, D.A. (2013). Free radical scavenging activities total phenolic and flavonoid content of lipidum sativum (Linn). International Journal of Pharmacy and Pharmaceutical Sciences, 2013, 5(4), 634- b637.

[36] Hęś, M., Dziedzic, K., Le Thanh-Blicharz, J., Kmiecik, D. and Górecka, D. (2016). Antioxidant activity of true aloe (Aloe vera) extract in model systems. Nauka Przyr. Technol., 10, 4, 53. DOI: http://dx.doi.org/10.17306/J. NPT.2016.4.53 
[37] Kumar, S. and Pandey, A.K. (2013). Chemistry and biological activities of flavonoids: An overview. Sci. World J. 2013, 2013, 162750. [CrossRef] [PubMed]

[38] Lopes, C.L.; Pereira, E.; Sokovi'c, M.; Carvalho, A.M.; Barata, A.M.; Lopes, V.; Rocha, F.; Calhelha, R.C.; Barros, L. and Ferreira, I.C.F.R. (2018). Phenolic composition and bioactivity of Lavandula pedunculata (Mill.) Cav. samples from different geographical origin. Molecules 2018, 23, 1037. [CrossRef] [PubMed]

[39] Sethiya, N., Trivedi, A. and Mishra, S. (2014). The total antioxidant content and radical scavenging investigation on 17 phytochemical from dietary plant sources used globally as functional food. Biomedicine and Preventive Nut., 4(3): 439-444

[40] Moskaug, J., Carlsen, H., Myhrstad, M. and Blomhoff, R. (2004). Molecular imaging of the biological effects of quercetin and quercetinrich foods. Mechanisms of Ageing and Dev., 125 (4): 315-324.

[41] Swanson, H. (2015). Flavonoids and the Inflammatory Response. Flavonoids, Inflammation and Cancer: world scientific; 2015. 59-104

[42] Maridonneau, PI and Harpey, C. (2012). Effect of trimetazidine on membrane damage induced by oxygen free radicals in human red cells. Brit $\mathrm{J}$ Clin Pharmaco 2012; 20(2): 148-151.

[43] Xiao, B.X. and Guo, J. (2009). The anti-proliferation and anti-migration dual effects of aloe-emodin on KB cells and its mechanism. Zhonghua Kou Qiang Yi Xue Za Zhi, 44, 50-2.

[44] Sundarraj, S., Thangam, R., Sreevani, V., Kaveri, K., Gunasekaran, P., Achiraman, S. and Kannan, S. (2012). g-Sitosterol from Acacia nilotica L. induces G2/M cell cycle arrest and apoptosis through c-Myc suppression in MCF-7 and A549 cells. J Ethnopharmacol. 14:803-809

[45] Jurasz, P., Alonso-Escolano, D., Radomski, MW. (2004). Plateletcancer interactions: mechanisms and pharmacology of tumour cell-induced platelet aggregation. Br J Pharmacol. 143:819-826.

[46] Hsu, HC., Yang, WC., Tsai, WJ., Chen, CC., Huang, HY., Tsai, YC. (2006|). Alpha-Bulnesene, a novel PAF receptor antagonist isolated from Pogostemon cablin. Biochem Biophys Res Commun. 345:1033-1038.

[47] Huang, PH., Huang, CY. and Chen, MC. (2013). Emodin and Aloe-Emodin Suppress Breast Cancer Cell Proliferation through ER $\alpha$ Inhibition. Evid Based Complement Alternat Med, 2013, 376123.

[48] Pan, Q., Pan, H., Lou, H. and Xu, Y. (2013). Inhibition of the angiogenesis and growth of Aloin in human colorectal cancer in vitro and in vivo. Cancer Cell Int, 13, 69. 